\title{
Study of Temperature and Time Steaming of Dough as Material of Analog Rice Making
}

\author{
I Gede Pasek Mangku ${ }^{1}$, I Nyoman Rudianta ${ }^{2}$, Luh Suryati ${ }^{3}$ \\ pasek_mangku@yahoo.com ${ }^{1}$, suryatiluh1@gmail.com²
}

\section{Agriculture Faculty of Warmadewa University, Bali, Indonesia}

\begin{abstract}
Carbohydrates used in the manufacture of analog rice dough can come from sources of cereals and tubers, both in the form of starch and flour form as a whole. The factors that determine the quality of analog rice as a substitute for rice are, amylose and amylopectin ratios, protein content, starch gelatinization temperature, development of volume, water absorption, gel viscosity, and consistency of starch gel. This research is a factorial experiment with Randomized Block Design (RBD) consisting of two factors, namely: factor I, steaming temperature $(\mathrm{P})$, which consists of 3 levels of treatment, namely: steaming temperature $70^{\circ} \mathrm{C} \pm 5^{\circ} \mathrm{C}(\mathrm{P} 1) ; 80^{\circ} \mathrm{C} \pm 5^{\circ} \mathrm{C}(\mathrm{P} 2)$; and $90^{\circ} \mathrm{C}$ $\pm 5^{\circ} \mathrm{C}$ (P3). Factor II: Time of steaming (W), which consists of three types of treatment, namely: (W1) = steaming for 20 minutes; $(\mathrm{W} 2)=30$ minutes; $(\mathrm{W} 3)=40$ minutes. The data obtained will be analyzed by ANOVA and followed by LSD test $(5 \%)$ if the treatment has a significant effect $(\mathrm{P}<0.05)$. This study aims to determine and analyze the effect of temperature and time of steaming on the chemical and sensory properties of the dough.The results showed that the interaction of temperature and steaming time had a significant effect $(\mathrm{P}<0.05)$ on the moisture content of the dough but had no effect $(\mathrm{P}>0.05)$ on fat content and amylose. The average value of the dough water content ranged from $52,736-59,627 \%$. The highest water content of the dough was $59,627 \%$ produced by steaming treatment at $80^{\circ} \mathrm{C} \pm 5^{\circ} \mathrm{C}$ for 20 minutes. While the lowest water content of the dough was $52.736 \%$ and the steaming treatment temperature was $70^{\circ} \mathrm{C} \pm$ $5^{\circ} \mathrm{C}$ for 40 minutes. The average value of fat content of the dough ranged from 2.452$4.003 \%$. The highest fat content of $4.003 \%$ was produced by a treatment temperature of $90^{\circ} \mathrm{C} \pm 5^{\circ} \mathrm{C}$ for 20 minutes, while the lowest fat content was $2.452 \%$ produced by the treatment of steaming temperature of $70^{\circ} \mathrm{C} \pm 5^{\circ} \mathrm{C}$ for 40 minutes. Amylose dough levels ranged from $0.014-0.055 \%$. The sensory test results showed that the average color values ranged from 1.93-3.67 (very dark-lightness), the highest color value of 3.67 (lightness) produced by a treatment temperature of $70^{\circ} \mathrm{C} \pm 5^{\circ} \mathrm{C}$ for 40 minutes. The highest odor value of 2.70 (agak langu) was produced by a temperature of $70^{\circ} \mathrm{C} \pm 5^{\circ} \mathrm{C}$ for 40 minutes and the highest texture value of the dough was 3.40 (smooth) produced by a treatment temperature of $70^{\circ} \mathrm{C} \pm 5^{\circ} \mathrm{C}$ for 40 minutes.
\end{abstract}

Keywords: Dough, steaming, taro, tofu, quality. 


\section{Introduction}

Rice is a staple food for most Indonesian people. Consumption of rice is increasing every year as the population increases. Indonesian rice consumption is around $139 \mathrm{~kg} /$ capita / year and is among the highest rice consumption countries in Asia [1]. Government programs in an effort to reduce rice consumption continue to be carried out through food diversification, with the target of consuming $70 \mathrm{~kg}$ / capita / year of rice as Malaysia and Thailand at $80 \mathrm{~kg} /$ capita / year. Indonesia has a great potential to produce agricultural products, a source of carbohydrates instead of rice. One approach that can be done is through making analog rice from various flour derived from non-rice raw materials [2].

Some of the factors that determine the quality of analog rice as a substitute for rice are, amylose and amylopectin ratio, protein content, starch gelatinization temperature, volume development, water absorption, gel viscosity, and consistency of starch gel [3]. According to [4] steaming for less time or less than optimal temperature causes galatinization to be less optimal. Steaming that is too long or the temperature is too high causes the development of starch granules because the water molecules penetrate into the starch granule more and more. Based on the results of previous studies, it has been shown that analog rice research uses steaming temperature and duration of dough has never been done. Therefore, more in-depth research needs to be done on the effect of temperature and duration of steaming on the chemical and sensory properties of the dough, so that dough can be produced that has good quality, safe, healthy and liked by the community.

Some of the problems that will be studied in this research are: does the steaming temperature affect the chemical and sensory properties of the dough produced?, does steaming time affect the chemical and sensory properties of the dough produced?, and what is the most appropriate temperature and duration of steaming in producing the dough with the best chemical and sensory properties.

Research purposes are: to find out and analyze the effect of steaming temperature on the chemical and sensory properties of the doug, to find out and analyze the effect of steaming time on the chemical and sensory properties of the dough produced, and. to determine the temperature and the right steaming time in making dough that has the best chemical and sensory properties.

\section{Research Methodh}

\subsection{Materials and Equipment}

The materials used in this study were taro tubers obtained from the Badung-Denpasar Market and for tofu pulp obtained from tofu craftsmen in Ubung Village, Denpasar. The chemicals used for analysis include: $\mathrm{Na}_{2} \mathrm{CO} 3$, distilled water, $\mathrm{CuSO}_{4} .5 \mathrm{H}_{2} \mathrm{O}$, HCL, LuffSchoorl $25 \mathrm{ml}$, KI 20\%, $\mathrm{H}_{2} \mathrm{SO}_{4} 26.5 \%$, Na-thiosulfate solution $0.1 \mathrm{~N}$, starch $1 \%$, $\mathrm{NaOH} 0,1 \%$ and iodine $0.01 \mathrm{~N}$.

The equipment used in the processing of taro flour and dregs flour knows including, flour grinding machine type disk mill, spiner, squeezer, 80 mesh sieve, drying oven, gas stove, wash basin, knife, $2 \mathrm{~kg}$ table scales. The equipment used for chemical analysis is burette with support, Kjeldahl flask, spectrophotometer, desiccator, analytical scales, measuring flask, 500 $\mathrm{ml}$ glass cup, $100 \mathrm{ml}$ cup glass, $10 \mathrm{ml}$ volume pipette, petri dish, mortar, erlenmeyer, funnel, stirring rod, etc. 


\subsection{Research Methods}

This research is a factorial experiment with Randomized Block Design (RBD) consisting of two factors, namely: factor I, steaming temperature (P), which consists of 3 levels of treatment, namely: steaming temperature $70^{\circ} \mathrm{C} \pm 5^{\circ} \mathrm{C}(\mathrm{P} 1) ; 80^{\circ} \mathrm{C} \pm 5^{\circ} \mathrm{C}(\mathrm{P} 2)$; and $90^{\circ} \mathrm{C} \pm 5^{\circ} \mathrm{C}(\mathrm{P} 3)$. Factor II: Time of steaming (W), which consists of three types of treatment, namely: $(\mathrm{W} 1)=$ steaming for 20 minutes; $(\mathrm{W} 2)=30$ minutes; $(\mathrm{W} 3)=40$ minutes. From the two factors and the level of treatment, 9 combined units of treatment and research were repeated 2 times so that all 18 units of treatment were obtained. Data obtained would be analyzed by ANOVA and followed by BNT test (5\%) if the treatment had significant effect ( $\mathrm{P}<0.05)[5]$.

\subsection{Research Place and Time}

This research will be conducted in several places, for the dough making process and the analysis will be carried out at the Laboratory of the Faculty of Agriculture, Agriculture Technology Department, Denpasar Warmadewa University and at the Food and Agriculture Laboratory at the Faculty of Agricultural Technology, Udayana University.

\subsection{Step of the Research}

Taro flour making is done using the method carried out by [6]. The stages of making taro flour include, stripping, washing, making, soaking with $10 \% \mathrm{NaCl}$ solution for 1 hour, washing with water, soaking with water for 3 hours, drying $35-50^{\circ} \mathrm{C}$ with sunlight for $3-4$ days, grinding, and sifting 80 mesh

Making tofu flour is done using the method carried out by [7]. Making tofu flour is done by drying the tofu dregs from the filtering of soybean milk at a temperature of $35-50^{\circ} \mathrm{C}$ for $6-7$ days using a sun dryer. Dried tofu waste is then ground until smooth and sifted with 80 mesh.

The next stage is the process of weighing taro flour and tofu flour with the proportion of the proportion of taro flour ingredients: tofu flour, namely: $60: 40 \%$ of the total weight of flour. Each formulation of this material was then put into a different stainless steel wash basin. In the material formulation $110 \%$ water was added and $2 \%$ alginate was added from the total weight of flour to each mixture formulation. The material is then mixed and stirred manually by hand until homogeneous.

At the last stage the mixture is cooked by steaming until the mixture is cooked and has been gelatinized. Steaming is done at the temperature according to the treatment given, namely; $70^{\circ} \mathrm{C} \pm 5^{\circ} \mathrm{C}, 80^{\circ} \mathrm{C} \pm 5^{\circ} \mathrm{C}$, and $90^{\circ} \mathrm{C} \pm 5^{\circ} \mathrm{C}$ for 20,30 and 40 minutes. The cooked mixture is then analyzed for chemical and sensory properties.

\subsection{Parameters}

To determine the effect of each treatment was observed the chemical properties: (amylose content, fat, and moisture content) and sensory test (color, texture, and odor).Determination of amylose content by method [8], moisture content with the Gravimetric method [9]; fat content with the Sochlet method [9]. Sensory evaluation (color, texture and odor) by [10].

\subsection{Data Analysis}

Data processing and analysis is done after the data is collected, tabulated, and analyzed by ANOVA, if the effect of real or very real treatment is obtained it will be followed by the Smallest Significant Difference test [5]. 


\section{Results and Discussion}

\subsection{Amylose Content}

The results of the variance analysis showed that the treatment of steaming temperature $(\mathrm{P})$, steaming time $(\mathrm{W})$ and its interaction had no significant effect $(\mathrm{P}>0.05)$ on the amylose content of the resulting dough. In Table 3.1, the amylose content of the dough produced ranged from $0.014-0.055 \%$. The highest amylose content of $0.055 \%$ was produced by the treatment of steaming temperature of $70^{\circ} \mathrm{C} \pm 5^{\circ} \mathrm{C}$ with a steaming time of 20 minutes, while the lowest amylose content was $0.014 \%$ produced by steaming temperatures of $80^{\circ} \mathrm{C} \pm 5^{\circ} \mathrm{C}$ for 20 minutes. Amylose content between all treatments showed no significant difference ( $\mathrm{P}>$ 0.05 ). The resulting dough has a very low amylose content. The level of carbohydrate (starch) will decrease which is caused by high temperature treatment will cause damage to some carbohydrate molecules during the processing. This means that the lower the amylose content, the greater the amylopectin level when viewed from the starch content of the mixture of $15.38 \%[11]$.

Table 3.1. The evarage Amylose Content (\%) of Dough affected by Temperatures and Time of Steaming.

\begin{tabular}{|c|c|c|c|c|}
\hline Treatments & \multicolumn{3}{|c|}{ Times of Steaming (minutes) } & \multirow{2}{*}{ Everages } \\
\cline { 1 - 4 } $\begin{array}{c}\text { Temperatures of Steaming } \\
\left( \pm 5^{\circ} \mathrm{C}\right)\end{array}$ & 20 & 30 & 40 & \\
\hline 70 & 0.055 & 0.047 & 0.017 & $0,040 \mathrm{a}$ \\
\hline 80 & 0.014 & 0.028 & 0.032 & $0,025 \mathrm{a}$ \\
\hline 90 & 0.026 & 0.030 & 0.036 & $0,031 \mathrm{a}$ \\
\hline Everages & $0,032 \mathrm{a}$ & $0,035 \mathrm{a}$ & $0,028 \mathrm{a}$ & \\
\hline
\end{tabular}

Remarks: The average value followed by the same letter in the same row or column shows a not significant difference $(P>0.05)$

\subsection{Fat Contents}

The results of the variance analysis showed that the treatment of steaming temperature $(\mathrm{P})$, steaming time $(\mathrm{W})$ and its interaction had no significant effect $(\mathrm{P}>0.05)$ on the fat content of the dough produced. In Table 3.2, the fat content of the dough produced ranges from 2.452$4.003 \%$. The highest fat content of $4,003 \%$ was produced by the treatment of steaming temperature of $90^{\circ} \mathrm{C} \pm 5^{\circ} \mathrm{C}$ with a steaming time of 20 minutes, while the lowest fat content was $2.452 \%$ produced by steaming temperatures of $70^{\circ} \mathrm{C} \pm 5^{\circ} \mathrm{C}$ for 40 minutes. Fat content between all treatments showed no significant difference $(\mathrm{P}>0.05)$. The longer the heating is done, the fat content of the dough tends to decrease. This is because the fat in the dough will be damaged at high temperature processing with a long heating time. According to [12], the level of fat damage varies greatly depending on the temperature and length of time used during processing. The higher the temperature used, the more intense the fat damage.

Table 3.1. The evarage Fat Content (\%) of Dough affected by Temperatures and Time of Steaming.

\begin{tabular}{|c|c|c|c|c|}
\hline Treatments & \multicolumn{3}{|c|}{ Times of Steaming (minutes) } & \multirow{2}{*}{ Everages } \\
\hline $\begin{array}{c}\text { Temperatures of Steaming } \\
\left( \pm 5^{\circ} \mathrm{C}\right)\end{array}$ & 20 & 30 & 40 & \\
\hline
\end{tabular}




\begin{tabular}{|c|c|c|c|c|}
\hline 70 & 3.141 & 3.650 & 2.452 & $3,081 \mathrm{a}$ \\
\hline 80 & 2.696 & 3.597 & 3.450 & $3,247 \mathrm{a}$ \\
\hline 90 & 4.003 & 3.572 & 3.153 & $3,576 \mathrm{a}$ \\
\hline Everages & $3,280 \mathrm{a}$ & $3,606 \mathrm{a}$ & $3,018 \mathrm{a}$ & \\
\hline
\end{tabular}

Remarks: The average value followed by the same letter in the same row or column shows a not significant difference $(P>0.05)$

\subsection{Water Content}

The results of the variance analysis showed that the interaction treatment between steaming temperature $(\mathrm{P})$ and steaming time $(\mathrm{W})$ had a significant effect $(\mathrm{P}<0.05)$ on the moisture content of the resulting dough. In Table 3.3 shows the highest water content value of $59,627 \%$ produced by the treatment of $80^{\circ} \mathrm{C} \pm 5^{\circ} \mathrm{C}$ steaming temperature with a steaming time of 20 minutes. While the lowest water content of the dough was $52.736 \%$ produced by the treatment of steaming temperature of $70^{\circ} \mathrm{C} \pm 5^{\circ} \mathrm{C}$ for 40 minutes. At the steaming temperature of $70^{\circ} \mathrm{C} \pm 5^{\circ} \mathrm{C}$, the tendency of the longer heating time is shown, the water content of the dough tends to decrease. This is because the longer the heating, the more water can be evaporated. According to [12], the greater the heat given and the longer the heating will result in reduced water content in large quantities of food.

Table 3.3. The evarage Moisture Content (\%) of Dough affected by Temperatures and Time of Steaming.

\begin{tabular}{|c|c|c|c|}
\hline Treatments & \multicolumn{3}{|c|}{ Times of Steaming (minutes) } \\
\hline $\begin{array}{c}\text { Temperatures of Steaming } \\
\left( \pm 5^{\circ} \mathrm{C}\right)\end{array}$ & 20 & 30 & 40 \\
\hline 70 & $\begin{array}{c}56.135 \mathrm{a} \\
\mathrm{b}\end{array}$ & $\begin{array}{c}54.299 \mathrm{~b} \\
\mathrm{a}\end{array}$ & $\begin{array}{c}52.736 \mathrm{~b} \\
\mathrm{~b}\end{array}$ \\
\hline 80 & $\begin{array}{c}59.627 \mathrm{a} \\
\mathrm{a}\end{array}$ & $\begin{array}{c}55.687 \mathrm{~b} \\
\mathrm{a}\end{array}$ & $\begin{array}{c}55.392 \mathrm{~b} \\
\mathrm{a}\end{array}$ \\
\hline 90 & $\begin{array}{c}54.061 \mathrm{a} \\
\mathrm{c}\end{array}$ & $\begin{array}{c}55.571 \mathrm{a} \\
\mathrm{a}\end{array}$ & $\begin{array}{c}54.756 \mathrm{a} \\
\mathrm{a}\end{array}$ \\
\hline
\end{tabular}

Remarks: The average value followed by the same letter in the same row or column shows a not significant difference $(P>0.05)$

\subsection{Sensories Evaluation}

In Table 3.4, it can be seen that an assessment of the product of the dough produced includes color, smell and texture. The level of panelists' preference for dough products is still relatively low, especially in terms of color and smell. Based on the assessment of the panelists on the color of the dough it is still very low, ranging from 1.67 (darkness) to 3.67 (lightness). The color of the dough produced tends to be brown rather dark so that the panelists are less favored. The level of preference of the panelists for odor is also still low, which ranges from 2.27-2.67 (beany flavor). While the panelist's assessment of texture ranges from 2.40-3.40 (crude-smooth). The average value of the panelist's assessment of color, odor and texture of the dough as shown in Table 3.4. 
Table 3.4 The Everages Value of Sensories Evaluation on Color, Odor and Texture of Dough in each of treatments

\begin{tabular}{|c|c|c|c|}
\hline \multirow{2}{*}{ Treatments } & \multicolumn{3}{|c|}{ Everages Value } \\
\cline { 2 - 4 } & Color & Odor & Texture \\
\hline Temperature of $70^{\circ} \mathrm{C} \pm 5^{\circ} \mathrm{C}, 20$ minutes & 2.07 & 2.27 & 2.73 \\
\hline Temperature of $70^{\circ} \mathrm{C} \pm 5^{\circ} \mathrm{C}, 30$ minutes & 2.80 & 2.33 & 2.67 \\
\hline Temperature of $70^{\circ} \mathrm{C} \pm 5^{\circ} \mathrm{C}, 40$ minutes & 3.67 & 2.70 & 3.40 \\
\hline Temperature of $80^{\circ} \mathrm{C} \pm 5^{\circ} \mathrm{C}, 20$ minutes & 1.67 & 2.33 & 2.60 \\
\hline Temperature of $80^{\circ} \mathrm{C} \pm 5^{\circ} \mathrm{C}, 30$ minutes & 2.67 & 2.40 & 2.40 \\
\hline Temperature of $80^{\circ} \mathrm{C} \pm 5^{\circ} \mathrm{C}, 40$ minutes & 3.33 & 2.53 & 3.33 \\
\hline Temperature of $90^{\circ} \mathrm{C} \pm 5^{\circ} \mathrm{C}, 20$ minutes & 1.93 & 2.67 & 2.53 \\
\hline Temperature of $90^{\circ} \mathrm{C} \pm 5^{\circ} \mathrm{C}, 30$ minutes & 2.47 & 2.40 & 2.67 \\
\hline Temperature of $90^{\circ} \mathrm{C} \pm 5^{\circ} \mathrm{C}, 40$ minutes & 2.80 & 2.53 & 2.73 \\
\hline
\end{tabular}

\subsubsection{Color}

In Table 3.4, the average sensory value of the color of the dough product shows the highest average color value of 3.67 (slightly lightness-lightness) given by the treatment, namely the treatment temperature of $70^{\circ} \mathrm{C} \pm 5^{\circ} \mathrm{C}, 40$ minutes. While the lowest average color value is 1.67 (darkness) given by a temperature of $80^{\circ} \mathrm{C} \pm 5^{\circ} \mathrm{C}, 20$ minutes. This is probably due to the higher temperature, the kenetic reaction that occurs in the dough will be faster during heating, causing a non-enzymatic browning reaction will occur more quickly as a result of the color of the resulting dough will be more brownish and fade.

\subsubsection{Odor}

The sensory mean value of the dough odor (Table 3.4) shows the lowest average odor value of 2.07 (beany flavor) given by the treatment temperature of $70^{\circ} \mathrm{C} \pm 5^{\circ} \mathrm{C}, 20$ minutes. While the highest average odor value of 2.67 (beany flavor) was given by a treatment temperature of $70^{\circ} \mathrm{C} \pm 5^{\circ} \mathrm{C}, 40$ minutes. This is because the tofu dregs contain odor-causing compounds so that the more addition of the dregs flour knows, the unpleasant smell that appears on the dough product will be higher. Tofu dregs contain high protein. $100 \mathrm{~g}$ of dried tofu pulp contains crude protein of $23.39 \%$ and crude fiber of $19.44 \%$ [7].

\subsubsection{Texture}

In Table 3.4, the average sensory value of the texture of the dough products performed by the panelists shows that the highest average texture value of 3.40 (smooth) is given by the treatment temperature of $70^{\circ} \mathrm{C} \pm 5^{\circ} \mathrm{C}, 40$ minutes. While the lowest average texture value is 2.40 (crude) given by a treatment temperature of $80^{\circ} \mathrm{C} \pm 5^{\circ} \mathrm{C}, 30$ minutes. The texture of the dough will be more preferred with increasing steaming temperature. This is because the texture of the dough produced besides being influenced by the type of material used can also be influenced by the heating process carried out. The higher the heating temperature given, the texture of the dough will be stronger and more compact.

Steaming for less or less optimal temperature causes galatinization to be less than optimal. Steaming that is too long or the temperature is too high causes the development of starch granules because the water molecules penetrate into the starch granule more and more [4]. 


\section{Conclusions and Suggestions}

\subsection{Conclusions}

1. The treatment of temperature and time of steaming and its interaction had a significant effect $(\mathrm{P}<0.05)$ on the moisture content of the dough but did not affect fat content and amylose content $(\mathrm{P}>0.05)$.

2. The lowest water content of the dough is $52.736 \%$ produced by the treatment of steaming temperature of $70^{\circ} \mathrm{C} \pm 5^{\circ} \mathrm{C}$ for 40 minutes. The highest fat content of $4,003 \%$ was produced by the treatment of heating temperature of $90^{\circ} \mathrm{C}$ with a heating time of 20 minutes and the highest amylose content of $0.055 \%$ produced by the treatment of steaming temperature $70^{\circ} \mathrm{C} \pm 5^{\circ} \mathrm{C}$ with a heating time of 20 minutes.

3. The results of sensory assessment of the dough show the highest average color, odor and texture values of 3.67 (less lightness-lightness), 2.67 (beany flavor) and 3.40 (smooth) produced by the treatment of steaming temperature $70^{\circ} \mathrm{C} \pm 5^{\circ} \mathrm{C}$ for 40 minutes.

\subsection{Suggestions}

1. To be able to produce a dough that has better quality in terms of water content, amylose content and fat content and sensory aspects (color, odor and texture), the dough should be processed using steaming at $70^{\circ} \mathrm{C} \pm 5^{\circ} \mathrm{C}$ for 20 minutes.

2. The product of the dough produced in terms of color and odor is still not favourable by the panelists, so for further research is needed to examine the aspects of color stability and to remove of off-flavor.

\section{References}

[1] S. B. Gultom, R.J, Sutrisno, "Optimasi Proses Gelatinisasi Berdasarkan Respon Surface Methodology pada Pencetakan Beras Analog dengan Mesin Twin Roll,” J. Pasca panen, vol. 11, no. 2, pp. 67-79, 2014.

[2] dan S. B. Noviasari, S., F. Kusnandar, "Pengembangan Beras Analog dengan Memanfaatkan Jagung Putih," J. Teknol. dan Ind. Pangan, vol. 24, no. 2, 2013.

[3] R. . dan T. E. Adicandra, "Beras Analog dari Ubi Kelapa Putih (Discorea alata L): Review.," J. Pangan dan Agroindustri, vol. 4, no. 1, pp. 383-390, 2016.

[4] F. G. Winarno, Kimia Pangan dan Gizi. Jakarta: PT Gramedia, 2008.

[5] R. G. dan J. R. T. Steel, Prinsip dan Prosedur Statistika. Jakarta: PT Gramedia Pustaka Utama, 1991.

[6] S. dan P. N. S. Lestari, "Uji organoleptik mi basah berbahan dasar tepung talas beneng (Xantoshoma undipes) untuk meningkatkan nilai tambah bahan pangan lokal Banten," Pros Semnas Masy Biodiv Indon, vol. 1, no. 4, pp. 941-946, 2015.

[7] D. A. dan S. S. Y. Putri, "Pengaruh Penambahan Tepung Ampas Tahu dan Jenis Koagulan pada Pembuatan Tahu Berserat," J. Pangan dan Agroindustri, vol. 4, no. 1, pp. 321-328, 2016.

[8] S. N. dan S. P. Susilawati, "Karakteristik Sifat Fisik dan Kimia Ubi Kayu (Manihot esculenta) Berdasarkan Lokasi Penanaman dan Umur Panen Berbeda," J. Teknol. Ind. dan Has. Pertan., vol. 13, no. 2, pp. 59-72, 2008.

[9] dan S. Sudarmadji, S.,B.Haryono, Prosedur Analisa untuk Bahan Makanan dan Pertanian. Yogyakarta: Liberty, 1997.

[10] S. . Soekarto, Penilaian Organoleptik untuk Industri Pangan dan Hasil Pertanian. Yogyakarta: Bharata Karya Aksara, 1985. 
[11] dan A. Syarfaini, M., F. Satrianegara, S. Alam, “Analsis Kandungan Zat Gizi Biskuit Ubi Jalar Ungu (Ipomea batatas L. Poiret) Sebagai Alternatif Perbaikan Gizi di Masyarakat," Public Heal. Sci. J., vol. 9, no. 2, pp. 138-152, 2017.

[12] A. L. Sundari, D., Almasyuhuri, "Pengaruh Proses Pemasakan Terhadap Komposisn Zat Gizi Bahan Pangan Sumber Protein,” Media Litbangkes, vol. 25, no. 4, pp. 235-242, 2015. 